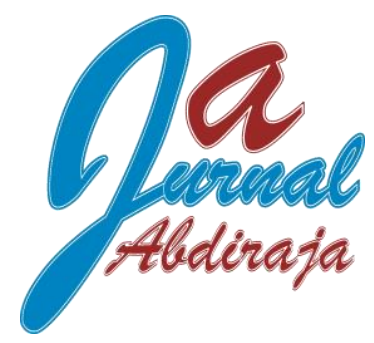

\title{
DIVERSIFIKASI OLAHAN DAN KEMASAN GULA KELAPA
}

\author{
Sayyida ${ }^{1}$ \\ Alwiyah ${ }^{2}$ \\ Ika Fatmawati Pramasari ${ }^{3}$
}

Volume 1, Nomor 1, September 2018

Universitas Wiraraja

\begin{abstract}
The technology of coconut sugar making in the area of research is still elementary. To increase the selling price of coconut sugar, needed product diversification, and packaging of processed coconut sugar. The target of a program is KWT Al Cholihah and KWT Al Fatah at District of Dungkek. One of processed coconut sugar offered in this program is the product of brown sugar. Packaging provided in this program is a plastic pouch packaging with the label image so that it can increase the shelf life and consumer appeal. Through the program science and technology to the Community on KWT Al Cholihah and KWT Al Fatah at District of Dungkek, the outcomes expected are as follows: (1) skilled members of KWT in the manufacture of brown sugar in attractive packaging, (2) Products is a product produced in brown sugar and coconut sugar in beautiful packaging and (3) increase in sales of coconut sugar and brown sugar. Based on the results of the implementation, the response of KWT members is apresiasif and positive. Positive response is seen from the desire of members to resume the manufacture of brown sugar for the domestic industry. After the members of the training, the participants are motivated to produce and begin to be marketed in the neighborhood. Results of print in packaging sugar production and brown sugar are now sold in some modern stores in Sumenep like Alfamart and outside of Sumenep.
\end{abstract}

Keyword: diversification, brown sugar, packaging

\section{PENDAHULUAN}

Kabupaten Sumenep memiliki keunggulan komperatif (comperative advantages) yang dapat dikembangkan oleh masyarakat sebagai potensi investasi yang cukup menjanjikan. Dengan sebagian besar masyarakat yang bekerja terkonsentrasi di sektor primer, banyak peluang yang dapat digarap menjadi suatu komoditi yang cukup menjanjikan, diantaranya adalah orientasi agribisnis.

Salah satu sektor yang dapat dioleh dengan cara agroindustri adalah sektor perkebunan. Kabupaten Sumenep dikenal sebagai sentra produksi kelapa dan juga telah ditetapkan sebagai musium kelapa Jawa Timur, karena banyaknya keanekaragaman varietas kelapa yang ada di Kabupaten Sumenep. Berdasarkan laporan tahunan data statistik perkebunan Dinas Perkebunan dan Kehutanan Kabupaten Sumenep (2013), produksi kelapa di Kabupaten Sumenep sebesar 2,763.22 ton dan luas arealnya mencapai 49,813.14 hektar.

Salah satu produk olahan kelapa adalah gula kelapa. Gula kelapa sebagai salah satu produk agroindustri atau yang lebih dikenal sebagai "Gula Jawa" atau "Gula Merah" merupakan hasil olahan nira kelapa (Cocos nucifera). Gula kelapa mempunyai peranan penting, terutama eksistensi dan fungsinya tidak dapat digantikan oleh jenis gula lain. Hal ini karena gula kelapa mengandung mineral, rasa, aroma, dan warna yang khas. Selain

\footnotetext{
${ }^{1}$ sayyida_unija@yahoo.com

2 alwiyahmahdaly@yahoo.com

3 ika_agribisnis@yahoo.co.id
} 
berfungsi sebagai pemanis, gula kelapa juga digunakan sebagai campuran bumbu masak, pembuatan kue, kecap, dodol, dan sebagainya.

Komoditas gula kelapa sebenarnya sudah cukup lama dikenal oleh masyarakat Indonesia dan mempunyai peluang utnuk menjadi komoditas ekspor. Gula kelapa dapat menjadi barang substitusi dari gula pasir, sehingga dapat didayagunakan untuk mengurangi ketergantungan impor gula. Tanaman kelapa di Kabupaten Sumenep umumnya tumbuh di wilayah pesisir yang masyarakatnya tergolong miskin, sehingga dengan menumbuh kembangkan usaha pembuatan gula kelapa, maka secara tidak langsung dapat menanggulangi kemiskinan (poverty alleviation).

Teknologi pembuatan gula kelapa cetak di Sumenep masih sangat sederhana, sehingga kapasitas produksi dan kualitas masih rendah. Untuk meningkatkan harga jual produk gula kelapa, diperlukan alternatif diversifikasi produk olahan dan kemasan gula kelapa. Selain itu kemasan gula kelapa cetak hanya dikemas dengan kantong plastik. Bahan kemasan yang sederhana ini ini tentu menjadikan gula kelapa tidak tahan disimpan dan besar kemungkinan akan terkontaminasi serta menjadikan produk perhatian para pengrajin, seharusnya kemasan mampu memperpanjang daya simpan dan kenampakan menjadi lebih flavor gula kelapa.

Salah satu olahan gula kelapa yang ditawarkan dalam program ini dan dapat meningkatkan penjualan adalah produk gula semut. Kemasan yang ditawarkan dalam program ini adalah kemasan plastic pouch dengan label gambar, sehingga bisa meningkatkan umur simpan dan daya tarik konsumen.

\section{METODE}

Metode dan tahapan pelaksanaan kegiatan ini, meliputi; (1) Sosialisasi, (2) Penyusunan modul pelatihan penerapan IbM; (3) Penyiapan sarana dan prasarana; (4) Pelaksanaan pelatihan (pada tahap ini diberikan pelatihan teknologi proses pengolahan gula semut, mulai dari teknik penyiapan bahan dan alat, proses pengolahan, teknik pengemasan sampai kepada perhitungan usaha); dan (5) Pemantauan dan refleksi.

\section{PEMBAHASAN}

Pelaksanaan program pengabdian kepada masyarakat ini dibagi dalam beberapa tahap, diantaranya adalah sebagai berikut.

Pertama, Sosialisasi. Pada tahap ini dilakukan kegiatan berupa kegiatan perijinan dan persiapan pelaksanaan pelatihan. Hasil yang diperoleh adalah kesepakatan dengan kelompok wanita tani mengenai waktu, lokasi dan pelaksanaan kegiatan. Pada kegiatan ini sudah melakukan pertemuan awal dengan KWT Al Cholifah dan KWT Al Fatah dan dihasilkan rencana kegiatan pengabdian kepada kelompok tani berdasarkan kebutuha. Dari hasil produksi gula kelapa cetak di tingkat pengrajin, masih dilakukan dengan peralatan yang sederhana, yaitu menggunakan kuali, pengaduk dan tungku kelapa cetak ini, dipasarkan ke pedagang pengumpul dan ada juga yang lansung dijual ke pasar tradisional. Selain daya simpan yang pendek, gula kelapa cetak di daerah penelitian memiliki kelemahan yaitu akses pasar masih terbatas (rendahnya tingkat pemanfaatan), dan harga yang berfluktuatif. Selain itu kemasan gula kelapa cetak hanya dikemas dengan kantong plastik. Bahan kemasan yang sederhana ini ini tentu menjadikan gula kelapa tidak tahan disimpan dan besar kemungkinan akan terkontaminasi serta menjadikan produk tidak menarik. 
Kedua, Penyusunan modul pelatihan penerapan $\boldsymbol{I}_{\boldsymbol{b}} \boldsymbol{M}$. Pada tahap ini diperoleh 3 modul untuk materi pelatihan yaitu: (1) modul teknologi proses pengolahan gula semut, (2) modul teknik pengemasan, dan (3) modul analisis usaha. Ketiga, Penyiapan sarana dan prasarana. Berdasarkan hasil wawancara diperoleh identifikasi kebutuhan alat untuk menunjang proses pengolahan gula semut. Pada kegiatan ini juga diberikan hibah alat-alat sesuai kebutuhan. Adapun alat tersebut dapat dilihat pada tabel 1.1 berikut ini.

\section{Tabel 1.1 Peralatan Kegiatan}

\begin{tabular}{|c|c|c|}
\hline No. & Nama Peralatan & Spesifikasi \\
\hline 1 & Oven & $\begin{array}{ll}\text { a. Merek } & \text { : Bima Boga } \\
\text { b. Type } & : 5545 \\
\text { c. Kapasitas } & : 12 \text { rak Loyang } \\
\text { d. Sumber panas: Gas LPG }\end{array}$ \\
\hline 2 & Mesin Penggiling & $\begin{array}{l}\text { : Moswell Single Phase Motor } \\
: \text { MW-125-2 } \\
: \text { 220V/50Hz } \\
: 2800 \text { RPM } \\
: 200 \mathrm{~W} \\
: 1,1 \mathrm{~A} \\
: \text { B }\end{array}$ \\
\hline 3 & Sealer & $\begin{array}{ll}\text { a. Merek } & \text { : double leopard } \\
\text { b. Type } & : \text { SP-200P } \\
\text { c. Ukuran } & : 20 \mathrm{~cm} \\
\text { d. Sumber panas : listrik } \\
\text { e. Volt } & : 220 \mathrm{~V}\end{array}$ \\
\hline
\end{tabular}

Selain itu juga diberikan kemasan plastik ukuran $10 \times 25 \times 010$, ukuran $15 \times 27 \times 010$ dan ukuran $20 \times 30 \times 010$ beserta dengan desainnya.

Keempat, Pelaksanaan pelatihan. Pada tahap ini mitra akan dilatih untuk mengenal teknologi proses pengolahan gula semut, mulai dari teknik penyiapan bahan dan alat, proses pengolahan, teknik pengemasan sampai kepada perhitungan usaha. Pelatihan pengemasan gula cetak dan pembuatan gula semut ini dilaksanakan pada tanggal 10 Juni 2015 di KWT Al Cholifah Desa Candi Kecamatan Dungkek Kabupaten Sumenep. Pelatihan ini diikuti oleh 15 orang anggota KWT Al Cholifah. Sementara di KWT Al Fatah Desa Romben Barat dilaksanakan tanggal 13 Juni 2015 dan diikuti oleh 15 orang anggota KWT Al Fatah. Pelatihan ini berlangsung dengan lancar dimana para peserta menujukkan ketertarikan terhadap cara pembuatan gula semut, hal ini ditunjukan dengan respon KWT cukup apresiasif dan positif. Respon positif terlihat dari keinginan anggota untuk melanjutkan pembuatan gula semut untuk industri rumah tangga. Pada tahap ini, juga dilakukan penyerahan bantuan alat untuk menunjang keberlanjutan usaha gula cetak kemasan dan gula semut. Setelah anggota mengikuti pelatihan, peserta termotivasi untuk memproduksi dan mulai dipasarkan di lingkungan sekitar. Hasil produksi gula cetak dalam kemasan dan gula semut saat ini sudah dijual di beberapa toko di Sumenep. 
Selanjutnya, dari kegiatan pengabdian masyarakat ini diperoleh hasil luaran sebagai berikut.

Pertama, Terampilnya untuk KWT Al Cholihah Desa Candi KWT Al Fatah dan Desa Romben Barat Kecamatan Dungkek dalam pembuatan gula semut dalam kemasan yang menarik. Sebelum kegiatan pengabdian masyarakat ini KWT Al Cholifah dan KWT Al Fatah hanya memproduksi gula cetak dan dipasarkan di pasar-pasar tradisional di lingkungan sekitar tanpa kemasan. Setelah kegiatan ini 16 anggota KWT dari 30 peserta pelatihan tidak hanya memproduksi gula cetak tapi memproduksi gula semut yang dikemas dalam kemasan menarik. Sisanya masih belum mencoba untuk membuat gula semut tetapi sudah memproduksi gula cetak dalam kemasan. Hal ini menunjukkan bahwa hasil kegiatan ini diperoleh adanya peningkatan variasi produk olahan dari gula kelapa cetak menjadi gula semut.

\section{Kedua, Produk yang dihasilkan adalah produk gula semut dan gula kelapa} dalam kemasan menarik (siap dipasarkan). Setelah kegiatan pengabdian ini anggota hanya membuat produk setengah jadi untuk produk gula semut. Proses pengemasan dilakukan di satu tempat yang ditunjuk oleh kelompok dengan menggunakan label kelompok. Produksi gula semut menggunakan alat-alat yang telah diberikan seperti: oven, mesin penggiling, seller. Hasil penjualan sebagian disimpan dalam kas kelompok untuk pengembangan kegiatan kelompok. Pemasaran gula cetak dan gula semut dalam kemasan yang diproduksi KWT Al Cholifah saat ini sudah menjangkau pasar modern seperti gerai Disperindag kerjasama Alfamart di wilayah Sumenep. Selain itu pemasaran gula semut ini dicoba untuk wilayah luar Sumenep seperti Surabaya, Jakarta dan Makasar. Hal ini menunjukkan bahwa telah berkembangnya jaringan pemasaran gula kelapa dan gula semut sampai luar daerah Sumenep.

Ketiga, Peningkatan penjualan gula kelapa dan gula semut. Dari hasil penjualan gula cetak dan gula semut yang dikemas ternyata mampu meningkatkan pendapatan, hal ini bias dilihat dari peningkatan penjualan dan harga jual menjadi lebih tinggi dari sebelumnya. Harga gula kelapa sebelum dikemas antara-Rp.9.000-12.000 per kg. Setelah dikemas dengan menarik harganya menjadi Rp. 15.000 per kg. Untuk gula semut harganya Rp. 30.000 per kg.

Indikator yang digunakan sebagai ukuran keberhasilan kegiatan yang dilakukan, antara lain meliputi: (1) Kehadiran peserta mengikuti kegiatan mencapai $100 \%$; (2) Semangat/antusiasme peserta mengikuti kegiatan baik; (3) Kemampuan/keterampilan peserta mengolah gula semut baik; (4) Tanggapan/respon peserta terhadap; dan (5) Pelaksanaan kegiatan positif.

\section{SIMPULAN}

Kegiatan $\mathrm{I}_{\mathrm{b}} \mathrm{M}$ Diversifikasi Olahan dan Kemasan Gula Kelapa telah dapat dijalankan dengan baik dan tanpa halangan yang berarti. Dengan kerjasama tim pengabdian yang baik dan peran serta aktif dari penyuluh/narasumber dalam kegiatan pengabdian ini maka semuanya telah berjalan sesuai yang diharapkan dan harapannya dapat memberikan manfaat bagi mitra pengabdian masyarakat dalam keberlanjutan usaha.

Respon anggota KWT cukup apresiasif dan positif. Respon positif terlihat dari keinginan anggota untuk melanjutkan pembuatan gula semut untuk industri rumah tangga. Setelah anggota mengikuti pelatihan, peserta termotivasi untuk memproduksi dan mulai dipasarkan 
di lingkungan sekitar. Hasil produksi gula cetak dalam kemasan dan gula semut saat ini sudah dijual di beberapa toko modern di Sumenep seperti gerai Disperindag kerjasama dengan Alfamart dan wilayah di luar Sumenep.

\section{DAFTAR RUJUKAN}

Herman, HS. 1984. Diversifikasi Produk Gula Merah. Balai Besar Penelitian dan Pengembangan Industri Pertanian: Bogor.

Soetanto, NE. 1998. Membuat Gula Kelapa Kristal. Penerbit Kanisius: Yogyakarta.

http://tanimakmursejahtera.blogspot.com diakses pada tanggal 6 April 2014 